\title{
HUBUNGAN RIWAYAT STIMULASI MOTORIK HALUS TERHADAP KEMAMPUAN BACA TULIS ANAK USIA 5 - 6 TAHUN
}

\section{THE RELATIONSHIP OF HISTORY OF FINE MOTORIC STIMULATION TO THE ABILITY OF READING WRITING CHILDREN AGED 5 - 6 YEARS}

\author{
Yusnita $^{1}$, Indry Yanti Azizah ${ }^{2}$, Desi Kurniawati ${ }^{3}$ \\ 1,2,3 Fakultas Kesehatan Universitas Muhammadiyah Pringsewu \\ Email Correspondence: yusnita@umpri.ac.id
}

\begin{abstract}
The Relationship Of History Of Fine Motoric Stimulation To The Ability Of Reading Writing Children Aged 5 - 6 Years. Fine motor stimulation is an activity to stimulate children's basic abilities such as reading and writing, carried out as an effort to educate children. Developmental abilities by stimulating fine motor skills can affect a child's writing and reading development. This study aims to determine the relationship between a history of fine motor stimulation on the literacy skills of children aged 5-6 years at Aisyiyah Ambarawa Pringsewu Kindergarten in 2021. The method used in this study is an analytical survey with a cross sectional approach, the sampling technique used is Total Sampling with the number of 70 respondents. Data was collected by using a questionnaire and statistical analysis using Chis-quare $(\mathrm{a}=0.05)$. The results of the study, a history of fine motor stimulation as many as $48(68.6 \%)$ children had a history of fine motor stimulation in the poor category and the literacy skills of children aged 5-6 years as many as $49(70.0 \%)$ children had poor literacy categories. There is a relationship between a history of fine motor stimulation on the literacy skills of children aged 5-6 years with a p-value of $0.043<0.05$. There is a relationship between a history of fine motor stimulation and literacy in children aged 5-6 years. This study can be used as information for respondents to pay more attention to the history of fine motor stimulation on the literacy skills of children aged 5 to 6 years. Keywords: Fine motor, reading and writing ability.
\end{abstract}

\begin{abstract}
Abstrak: Hubungan Riwayat Stimulasi Motorik Halus Terhadap Kemampuan Baca Tulis Anak Usia 5 - 6 Tahun. Stimulasi motorik halus merupakan kegiatan merangsang kemampuan dasar anak seperti baca dan tulis, dilakukan sebagai salah satu upaya mencerdaskan anak. Kemampuan perkembangan dengan menstimulasi motorik halus dapat mempengaruhi perkembangan menulis dan membaca anak. Penelitian bertujuan untuk mengetahui hubungan antara riwayat stimulasi motorik halus terhadap kemampuan baca tulis anak usia $5-6$ tahun di TK Aisyiyah Ambarawa Pringsewu tahun 2021. Metode yang digunakan dalam penelitian ini yaitu survei analitik dengan pendekatan Cros Sectional, teknik sampling yang digunakan yaitu Total Sampling dengan jumlah 70 responden. Pengumpulan data dilakukan dengan kuesioner dan analisis stastistik mengunakan Chis-quare $(\mathrm{a}=0,05)$. Hasil penelitian, riwayat stimulasi motorik halus sebanyak 48 ( 68,6\%) anak memiliki riwayat stimulasi motorik halus kategori kurang dan kemampuan baca tulis anak usia 5 - 6 tahun sebanyak 49 (70,0\%) anak memiliki kemampuan baca tulis kategori kurang. Ada hubungan antara riwayat stimulasi motorik halus terhadap kemampuan baca tulis anak usia $5-6$ tahun dengan hasil p-value $0,043<0,05$. Terdapat hubungan riwayat stimulasi motorik halus terhadap kemampuan baca tulis anak usia $5-6$ tahun. Penelitian ini dapat digunakan sebagai informasi kepada responden untuk lebih memperhatikan riwayat stimulasi motorik halus terhadap kemampuan baca tulis anak usia 5 - 6 tahun.
\end{abstract}

Kata Kunci : Motorik halus, kemampuan baca tulis. 
Vol 11 No 1 Januari 2022 | Page 165-169

\section{PENDAHULUAN}

Menurut UNICEF tahun 2011 didapat data masih tingginya angka kejadian gangguan pertumbuhan dan perkembangan pada anak usia balita khususnya gangguan perkembangan motorik didapatkan (27,5\%) atau 3 juta anak mengalami gangguan. Balita di Indonesia Sekitar 16\% di laporkan mengalami gangguan perkembangan berupa gangguan kecerdasan akibat gangguan perkembangan otak, gangguan pendengaran dan gangguan motorik (Warlenda VS, dkk, 2019). Penduduk Indonesia usia 0-2 tahun sebanyak 14.228.917 jiwa, sementara balita dengan interval umur 1-4 tahun berjumlah 19.388.917 jiwa, Sekitar 16\% dari anak usia dibawah lima tahun (balita) di Indonesia mengalami gangguan perkembangan saraf dan otak mulai ringan sampai berat. Sekitar 5-10\% anak diperkirakan mengalami keterlambatan perkembangan. Jumlah penduduk di Indonesia tahun 2015 pada program pembangunan kesehatan anak usia pra sekolah sebanyak 9,7 juta. Cakupan pelayanan kesehatan anak yang terdiri dari pemantauan perkembangan dan stimulasi dini tumbuh kembang mencapai $75,82 \%$. Hasilnya belum mencapai target renstra pada tahun 2014 yang sebesar 85\%. Hasil capaian tahun 2014 sudah meningkat dibanding pada tahun 2013 yaitu sebesar 70,12\% (Kemenkes, 2014).

Angka buta huruf pada anak usia 5-6 tahun di Indonesia 56,34\%. Hal 108 Presentase angka buta huruf usia 5-17 tahun di Provinsi Lampung 12,60\% (Susenas, 2018). Pringsewu di salah satu sekolah Taman Kanak - Kanak, terdapat 70 siswa kelompok bermain usia 5-6 th. Terdapat 15 anak yang mengalami keterlambatan kemampuan membaca dan menulis. Stimulasi motorik halus penting untuk perkembangan anak, seperti kemampuan dasar menulis dan membaca permulaan. Ini sejalan dengan penelitian sebelumnya yang dilakukan oleh Shihiyah. Z dan Nidia. M (2017), mengatakan bahwa kemampuan dasar menulis merupakan kemampuan yang harus dikembangkan dalam perkembangan bahasa anak. Kemampuan perkembangan dengan menstimulasi motorik halus dapat mempengaruhi perkembangan menulis anak.

Keterlambatan motorik dapat menyebabkan anak merasa rendah diri, kecemburuan terhadap anak lain, kekecewaan terhadap sikap orangtua, penolakan sosial, ketergantungan dan malu. Oleh karena itu, stimulasi ini harus diberikan secara rutin dan berkesinambungan dengan kasih sayang, metode bermain dan lain lain, sehingga perkembangan anak dapat berjalan secara optimal (Proborini A, dkk, 2017). (Hasyim \& Saputri, 2021)Oleh karena itu orang tua memiliki peran penting dalam menstimulasi perkembangan anak karena menjadi orang terdekat bagi anak. Stimulasi yang dilakukan orang tua dalam menunjang perkembangnya yaitu stimulasi kemampuan gerak kasar, stimulasi kemampuan gerak halus, stimulasi kemampuan bicara dan bahasa serta stimulasi kemampuan sosialisasi dan kemandirian (Sulistyawati. A, 2014). Tujuan penelitian adalah Mengetahui hubungan riwayat stimulasi motorik halus terhadap kemampuan baca tulis anak usia 5-6 tahun di TK Asyiyah Ambarawa Pringsewu. Penelitian dilaksanakan melalui tahap persiapan seperti: perizinan, survei dan pembuatan proposal penelitian; dan tahap pelaksanaan seperti: pengumpulan data, pengolahan data dan Analisa data.

\section{METODOLOGI}

Jenis penelitian ini yaitu survei analitik dengan pendekatan Cros Sectional. Teknik sampling yang digunakan yaitu Total Sampling. Sampel dalam penelitian adalah seluruh anak usia 5 - 6 tahun dan sampel yang diperoleh 70 responden. Penelitian dilaksanakan di TK Asyiyah Ambarawa Kecamatan Ambarawa Kabupaten Pringsewu pada bulan Juni - Agustus 2021. Pengumpulan data dilakukan dengan lembar kuesioner yang terdiri dari 10 pertanyaan mengenai riwayat stimulasi motorik halus dan 10 pertanyaan mengenai kemampuan baca tulis anak usia 5-6 tahun dan analisis stastistik mengunakan Chis-quare. 
Vol 11 No 1 Januari 2022 | Page 165-169

\section{HASIL}

Tabel 1. Distribusi frekuensi Riwayat stimulasi motorik halus pada anak usia 5 - 6 tahun.

\begin{tabular}{|c|c|c|c|}
\hline $\begin{array}{l}\text { Riwayat } \\
\text { Motorik Halus }\end{array}$ & Stimulasi & Frekuensi & $\begin{array}{l}\text { Persentase } \\
(\%)\end{array}$ \\
\hline Baik & & 22 & 31,4 \\
\hline Kurang & & 48 & 68,6 \\
\hline Jumlah & & 70 & 100 \\
\hline
\end{tabular}

Tabel 2. Distribusi frekuensi kemampuan baca tulis pada anak usia 5-6 tahun.

\begin{tabular}{lll}
\hline $\begin{array}{l}\text { Kemampuan Baca Tulis } \\
\text { Anak Usia 5-6 tahun }\end{array}$ & Frekuensi & $\begin{array}{l}\text { Persentase } \\
(\%)\end{array}$ \\
\hline Baik & 21 & 30,0 \\
\hline Kurang & 49 & 70,0 \\
\hline Jumlah & 70 & 100 \\
\hline
\end{tabular}

Table 3. Hubungan antara Riwayat stimulasi motoric halus terhadap kemampuan baca tulis pada anak usia 5-6 tahun.

\begin{tabular}{|c|c|c|c|c|c|c|c|c|}
\hline \multirow{3}{*}{$\begin{array}{l}\text { Riwayat } \\
\text { Stimulasi } \\
\text { Motorik Halus }\end{array}$} & \multicolumn{4}{|c|}{$\begin{array}{c}\text { Kemampuan Baca Tulis } \\
\text { Anak 5-6 Tahun }\end{array}$} & \multicolumn{2}{|c|}{ Total } & \multirow{3}{*}{$\begin{array}{l}\mathrm{P} \\
\text { Value }\end{array}$} & \multirow{3}{*}{$\begin{array}{l}\text { OR } \\
(\mathrm{CI}= \\
95 \%)\end{array}$} \\
\hline & \multicolumn{2}{|c|}{ Baik } & \multicolumn{2}{|c|}{ Kurang } & \multirow{2}{*}{$\mathrm{N}$} & \multirow{2}{*}{$\%$} & & \\
\hline & $\mathrm{N}$ & $\%$ & $\mathrm{~N}$ & $\%$ & & & & \\
\hline Baik & 3 & 13,6 & 19 & 86,4 & 22 & $\begin{array}{l}31, \\
4 \%\end{array}$ & & \\
\hline Kurang & 18 & 37,5 & 30 & 62,5 & 48 & $\begin{array}{l}68, \\
6 \%\end{array}$ & 0,043 & 0,203 \\
\hline Jumlah & 21 & 30,0 & 49 & 70,0 & 70 & 100 & & $\begin{array}{l}- \\
1,106\end{array}$ \\
\hline
\end{tabular}

Dari table 1. didapatkan sebanyak $48(68,6 \%)$ diberikan stimulasi motorik halus dengan katagori kurang. Tabel 2. Menunjukkan hasil 49(70,0\%) anak umur 5 - 6 tahum memiliki kemampuan baca tulis kategori kurang.

Tabel 3. diketahui responden dengan riwayat stimulasi motorik halus kategori baik sebanyak 3 $(13,6 \%)$ anak, dan anak yang mempunyai riwayat stimulasi motorik halus kategori kurang sebanyak 18 (37,5\%), sedangkan anak yang memiliki kemampuan baca tulis kategori baik sebanyak 19(86,4\%) dan anak yang memiliki kemampuan baca tulis kategori kurang sebanyak 30 (62,5\%). Hal ini dapat disimpulkan bahwa dengan uji Chi Square didapatkan hasil bahwa terjadi $p$-value $(0,043)$ yang berarti < $5 \%(0,05)$ dan menunjukan bahwa adanya hubungan antara riwayat stimulasi motorik halus terhadap kemampuan baca tulis anak usia 5 - 6 tahun di TK Aisyiyah Ambarawa Pringsewu.

\section{PEMBAHASAN}

Hasil menunjukkan bahwa anak yang tidak diberikan stimulasi motorik halus secara optimal berpengaruh terhadap kemampuan baca dan tulisnya. Dengan adanya anak yang diberikan stimulasi motorik halus dengan baik karena orang tuanya memperhatikan dan memberikan stimulasi dengan optimal sejak dini. Hasil penelitian diketahui bahwa anak yang riwayat stimulasi kategori baik sebanyak 3 ( 13,6\%) anak, dan anak yang mempunyai riwayat stimulasi kategori kurang sebanyak 18 (37,5\%), sedangkan anak yang memiliki kemampuan baca tulis kategori baik sebanyak $19(86,4 \%)$ dan anak yang memiliki kemampuan baca tulis kategori kurang sebanyak 30 (62,5\%). Hal ini sejalan dengan penelitian Lilis. M (2018) di TK Sumur genuk babat lamongan didapatkan anak 13 anak mengalami perkembangan motorik halus kurang, dan di Tk darma wanita kanor bojonegoro 16 anak di dapatkan perkembangan motorik halusnnya kategori kurang dengan hasil p-value 0,001, berdampak pada 
Vol 11 No 1 Januari 2022 | Page 165-169

perkembangan anak tersebut tidak sesuai dengan usia, cenderung adanya gangguan pada sistem saraf atau serebal palsi. Anak yang sudah mengalami cerbral palsi ini mempunyai karakteristik gerakan menulis yang tidak terkontrol dan perlahan, menujukkan koordinasi yang buruk berjalan tidak stabil, kesulitan melakukan gerakan cepat dan tepat misalnya susah menulis dan mengancing baju.

Penelitian Nunung. N, dkk (2017) dengan hasil p-value 0,001 mengatakan bahwa anak yang telah diberikan stimulasi perkembangan motorik halusnya lebih baik daripada anak yang tidak diberikan stimulasi motorik halus. Kemampuan motorik halus sangat penting karena berpengaruh pada segi pembelajaran lainnya terlebih pada segi akademis seperti menulis, mengguntinh, mewarnai dan lain lain. Penguasaan motorik halus penting bagi anak, karena seiring dengan semakin banyaknya ketrampilan motorik yang dimiliki semakin baik penyesuaian sosial yang dapat dilakukan anak yang dan akan berpengaruh pada semakin baiknya prestasi anak disekolah.

Menurut Saraswati (2013) perkembangan anak dipengaruhi oleh dua faktor yaitu faktor internal dan eksternal, faktor eksternal adalah stimulasi. Perkembangan anak akan dipengaruhi oleh lingkungan keluarga juga karena anak akan lebih cepat menirukan sesuatu dari apa yang dilihat, didengar, dan dirasakan. Perkembangan pada anak tiap anak berbeda - beda semua itu tergantung kepada pembelajaran apa yang didapatkan oleh anak, terutama pembelajaran dari orang tuanya karena orang tua merupakan pengaruh yang sangat besar terhadap perkembangan anaknya.

\section{SIMPULAN}

Dapat disimpulkan bahwa hasil penelitian ini ada hubungan signifikan hubungan antara riwayat stimulasi motorik halus terhadap kemampuan baca tulis anak usia 5 - 6 tahun di TK Aisyiyah Ambarawa Pringsewu Tahun 2020 dengan uji chi square dengan hasil p-value 0,043<0,05 sehingga ho ditolak.

\section{SARAN}

Penelitian ini dapat digunakan sebagai informasi kepada responden untuk lebih memperhatikan riwayat stimulasi motorik halus terhadap kemampuan baca tulis anak usia $5-6$.

\section{DAFTAR PUSTAKA}

Hasyim, D. I., \& Saputri, N. (2021). Deteksi Dini dan Edukasi Gangguan Pertumbuhan dan Perkembangan Pada Balita di Desa Podomoro Kabupaten Pringsewu. JURNAL BAGIMU NEGERI, 5(1), 10-14. https://ejournal.umpri.ac.id/index.php/bagimunegeri/article/view/1459/811

Kemenkes. (2014). Profil Kesehatan Indonesia 2014. Jakarta Kemenkes.

Lilis, M. (2018). Metode Bermain Puzzle Berpengaruh Pada Perkembangan Motorik Halus Anak Usia Prasekolah. Jurnal Endurance, 6. doi:http://doi.org/10.22216/jen.v3il.2488

Nunung, N., Catharina, S., \& Borneo, P. A. (2017). Pengaruh Finger Painting Terhadap Perkembangan Motorik Halus Anak Prasekolah di TK At-Taqwa. Jurnal Keperawatan BSI, Voluime V No. 2 , 9.

Poborini, A., Maulidha, \& Larasati, D. (2017). Faktor - Faktor yang Mempengaruhi Keterlambatan Perkembangan Anak Usia 1-3 Tahun Volume 1 Nomor 1, 51-70.

Saraswati. (2013). Diary Anakku memahami Tumbuh kembang anak usia 0 - 6 tahun Surabaya: Rona Publishing.

Shihiyah, Z., \& Nidia, M. (2017). Permainan Dakon Writing Therapy Untuk Mengembangkan Kemampuan Dasar Menulis Anak Kelompok A Tk Aisyiyah 33 Surabaya. Jurnal Pedagogi, Volume 3 Nomor $3 b 5$.

Susenas. (2018). Profil Anak Indonesia. Kementrian Kesehatan Republik Indonesia. Retrieved from https://www.kemenpppa.go.id/lib/uploads/list/74d38-buku-pai-2018.pdf

Sulistyawati, A. (2014). Deteksi Tumbuh Kembang Anak Jakarta Selatan: Salemba Medika

https://ejournal.umpri.ac.id/index.php/JIK $\mathbf{1 6 8}$ 
Vol 11 No 1 Januari 2022 | Page 165-169

Warlenda VS, Marlina H, \& R, R. (2019). Perkembangan Motorik Halus Balita Usia 3 - 4 Tahun di Paud Se- Kecamatan Rengat Barat. Jurnal Ilmiah Kesehatan, Volume 14, 1-11. 